\title{
ISOLATION, CHARACTERIZATION OF ASPERGILLUS FUMIGATUS AND OPTIMIZATION OF CULTURAL CONDITIONS FOR AMYLASE PRODUCTION
}

\author{
P.V Ratnasri ${ }^{1}$, B.K.M Lakshmi ${ }^{2}$, K. Ambika Devi ${ }^{3}$, K.P.J Hemalatha ${ }^{4}$ \\ ${ }^{1,2,3}$ Research scholar, ${ }^{4}$ Professor, Department of Microbiology, Andhra University, Visakhapatnam-530 003, \\ Andhra Pradesh, India
}

\begin{abstract}
The soil samples were collected from different depths of paddy and sugarcane fields. The samples were primarily screened for isolation of amylase producing fungi. Among the isolated fungi, amylase producing isolates were identified by growing on starch agar media. The isolate $(15 F)$ which form the maximum zone of clearance on starch agar media by iodine was identified and it was subcultured on potato dextrose agar (PDA). The isolate $(15 F)$ was morphologically characterized by performing cotton blue staining and scanning electron microscopic observations under required magnifications. Molecular characterization of isolate $(15 F)$ was performed by ITS/5.8S rRNA and $\beta$-tubulin gene sequence analysis and it was confirmed as Aspergillus fumigatus (MTCC Acc No 11399). Optimization of cultural conditions for maximum production of amylase was carried out by different cereal flours, incubation periods, temperatures, nitrogen sources and with different phosphate concentrations. Aspergillus fumigatus showed maximum amylase activity $\left(230 \pm 0.7 \mathrm{U} / \mathrm{mg}\right.$ protein) when cultured in finger millet at $35^{\circ} \mathrm{C}$ for $72 \mathrm{hrs}$ of incubation period.
\end{abstract}

Keywords: Amylase, Aspergillus fumigatus, cereal flour, submerged fermentation

\section{INTRODUCTION}

In modern times most important products of biological origin are enzymes, because they have numerous applications in various industrial processes. Among the industrial enzymes, starch degrading enzymes such as amylases gaining more importance in modern biotechnological era [1]. These enzymes are found in animals (saliva, pancreas), plants (malt), bacteria and fungi [2]. Being the most important sources for enzyme production the selection of suitable microorganisms plays a key role in high yield of desirable enzyme. The microbial amylases are the most important enzymes in present day biotechnology as they meet industrial demands. They have almost completely replaced chemical hydrolysis of starch in starch processing industries and have a great significant demand and they hold approximately $25 \%$ of the enzyme market [3]. Amylase is an amylolytic extracellular enzyme secreted by bacteria and fungi to carry out extracellular digestion. They break the insoluble starch into soluble end products such as glucose or maltose which are absorbed into their cells. Microbial amylases replace the chemical hydrolysis in starch saccharification [4]. Among the microbial production of amylases, fungal amylases are preferred over the bacterial sources mainly because of their more acceptable GRAS (Generally regarded as safe) status [1]. The fungal origin of amylases are more stable than the bacterial enzymes on a commercial scale [5, 2]. Molds are capable of producing high amounts of amylases [6]. Studies on fungal amylases, especially the developing countries have concentrated mainly on Rhizopus sp. and Aspergillus sp., probably because of their ubiquitous nature and non fastidious nutritional requirements of these organisms [7]. Amylases have potential applications in a number of industrial processes such as in food, baking, brewing, detergent, textile and paper industries. With the advent of new frontiers in biotechnology, the spectrum of amylase application has expanded into many other fields, such as clinical, medical and analytical chemistry [8]. The present work is undertaken for screening of amylase producing Aspergillus sp. from soil and optimization of cultural conditions for efficient production of amylases from cheaply available raw materials in the cost effective manner.

\section{MATERIALS AND METHODS}

\subsection{Collection of Soil Samples}

The soil samples were collected under sterile conditions to avoid contamination from different depths viz. $(10,15,20 \mathrm{cms})$ of paddy and sugarcane fields after their harvesting in Pendurthi, in Vijayanagaram District of Andhra Pradesh, India.

\subsubsection{Characterization of Soil}

Mineral matter of soil such as sand silt and clay contents were analyzed with the use of different sizes of sieves by the method of Alexander [9]. Soil pH was measured at 1:1.25 soil 
to water ratio using $\mathrm{pH}$ meter. Organic carbon content of soil was determined by Walkely and Black method [10], and total nitrogen content in soil was measured by the Microkjeldhal method [11]. Phosphorous in soil was measured by the method of Chapman and Pratti [12].

\subsection{Isolation of Fungal Isolates from Soil Samples}

One gram of each soil sample was suspended in the $9.0 \mathrm{ml}$ of sterile water. This sample was serially diluted by dilution plating method [13]. They were poured into PDA (potato dextrose agar) (Hi-Media) with chloramphenicol, a broad spectrum antibiotic used in inhibition of bacterial growth. The plates were incubated at $28^{0} \mathrm{C}$ for 2-3 days.

\subsection{Determination of Fungal Amylase Activity}

The fungal isolates were tested for amylase production by starch hydrolysis. The modified starch agar media (Soluble starch-2g, Peptone-2g, Yeast extract -1g, Agar-2g, Distilled water $-100 \mathrm{ml}$ at $\mathrm{pH} 6$ ) were inoculated with the isolates and incubated for $48 \mathrm{hrs}$ at $28^{\circ} \mathrm{C}$. After the completion of incubation period, the petridishes were flooded with the iodine solution, the zone of clearance formed around the microbial growth indicates the production of amylase.

\subsection{Characterization of Fungal Isolates}

\subsubsection{Microscopic Identification of Fungal Isolates}

Identification of fungal species was done as per the manuals of Domsch [14] and Barnett and Hunter [15]. After isolation of fungal isolate it was sub cultured on the PDA slants. Later it was primarily subjected to the Lacto phenol cotton blue staining, and then analyzed the morphology by Scanning Electron Microscope (JSM-6610 instrument model, JEOL/EO format) under required magnifications to observe morphology of mycelium and spore structures.

\subsubsection{Molecular Characterization of Fungal Isolates}

The molecular characterization of the fungal isolate was done by the gene sequence analysis of ITS/5.8S rRNA and $\beta$ tubulin gene, and construction of phylogenetic tree based on evolutionary relationship of taxa based on ITS sequence data and $\beta$-tubulin gene sequence data by Neighbor-Joining method [16]. The bootstrap consensus tree inferred from 100 replicates, which were taken to represent the evolutionary history of the taxa analyzed [17]. The evolutionary distances were computed using the Kimura2-parameter method [18] and evolutionary analyses were conducted in MEGA5 [19].

\subsection{Spore Harvesting and Storage}

After observing the amylase activity the fungal isolate was further used by harvesting the spores. The spores were harvested after the culture had been incubated for 14days. During this stage the culture was fully sporulated. The petridish was flooded with a mixture of $0.5 \mathrm{ml}$ sterile distilled water and $5.0 \mathrm{ml}$ of $0.05 \%$ Tween- 80 , then rubbed the culture gently with a sterile bent glass rod. The spores were released. Then the spore suspension was roughly filtered through sterilized glass wool positioned in the funnel into a $50 \mathrm{ml}$ Erlenmeyer flask. Spore suspensions were transferred directly to previously sterilized $50 \mathrm{ml}$ screw cap tubes and centrifuged for $5 \mathrm{mins}$ at $1000 \mathrm{rpm}$ at $4^{0} \mathrm{C}$ using REMI centrifuge. After centrifugation, supernatant was removed and the pellet was resuspended in $10 \mathrm{ml}$ sterile distilled water containing $0.1 \%$ (v/v) Tween-80, using vortex shaker for $30 \mathrm{sec}$ to suspend it completely. Then it was centrifuged once again to wash the spores free of debris. This process was repeated thrice and finally resuspended in $5.0 \mathrm{ml}$ sterile distilled water containing $0.1 \%$ (v/v) Tween-80 and shaken for 30sec before storage. The spore suspension was stored at $4^{0} \mathrm{C}$ in darkness until its requirement.

\subsection{Amylase Production}

The isolate $(15 \mathrm{~F})$ was subjected to fermentation medium containing $\quad\left(\mathrm{KH}_{2} \mathrm{PO}_{4}-0.14 \mathrm{~g}, \quad \mathrm{NH}_{4} \mathrm{NO}_{3}-1 \mathrm{~g}, \quad \mathrm{KCl}-0.5 \mathrm{~g}\right.$, $\mathrm{MgSO}_{4} .7 \mathrm{H}_{2} \mathrm{O}-0.01 \mathrm{~g}, \mathrm{FeSO}_{4} .7 \mathrm{H}_{2} \mathrm{O}-0.001 \mathrm{~g}$, soluble starch-2g, Distilled water-100ml at pH6.5). Erlenmeyer flasks were sterilized by autoclaving at $121^{\circ} \mathrm{C}$ for 15 mins. Spore suspension $(0.5 \mathrm{ml})$ was added and incubated in a shaking incubator for $48 \mathrm{hrs}$, at $200 \mathrm{rpm}$ and $28^{\circ} \mathrm{C}$ temperature.

\subsubsection{Extraction of Amylase from Fungal Isolates}

The fermented broth was centrifuged at $7000 \mathrm{rpm}$ for $30 \mathrm{mins}$. The cell free supernatant was used for the estimation of amylase.

\subsubsection{Demonstration of Enzyme Activity/Enzyme}

\section{Assay}

One milliliter of culture extract (enzyme) was pipetted into test tube, and $1.0 \mathrm{ml}$ of $1 \%$ soluble starch in citrate phosphate buffer $\mathrm{pH} 6.5$ was added and incubated in water bath at $40^{\circ} \mathrm{C}$ for 30mins. Then treated with DNS(Dinitro salicylic acid) and the reaction was stopped by boiling for 5 mins, and cooled to room temperature and $20 \mathrm{ml}$ of distilled water was added and color intensity was measured at 540nm. One unit of amylase activity was defined as the amount of enzyme that releases $1 \mu \mathrm{mol}$ of maltose per minute under the assay conditions. Activity of the enzyme is expressed in units per $\mathrm{mg}$ protein.

\subsection{Optimization of Cultural Conditions}

\subsubsection{Effect of Different Cereal Flours on Enzyme}

\section{Production}

The effect of different cereal flours such as sorghum, sammai, finger millet, pearl millet and horse gram on enzyme production was carried out at $\mathrm{pH} 5.6$ at $30^{\circ} \mathrm{C}$ for $48 \mathrm{hrs}$. 


\subsubsection{Effect of Temperature}

The effect of temperature on enzyme production was investigated by incubating the fermentation medium at $25^{\circ} \mathrm{C}$, $30^{\circ} \mathrm{C}, 35^{\circ} \mathrm{C}, 40^{\circ} \mathrm{C}$ and $45^{\circ} \mathrm{C}$ at $\mathrm{pH} 5.6$ for $90 \mathrm{hrs}$.

\subsubsection{Effect of Incubation Period}

The effect of incubation period on enzyme production was investigated by incubating the fermentation medium at regular intervals of $18,36,54,72$ and $90 \mathrm{hrs}$ at $\mathrm{pH} 5.6$ and at $35^{\circ} \mathrm{C}$.

\subsubsection{Effect of Different Nitrogen Sources}

The effect of different Nitrogen sources on enzyme production was investigated by adding ammonium nitrate, ammonium chloride, ammonium sulphate, and sodium nitrate separately to the fermentation medium and incubating them at $\mathrm{pH} 5.6$ for $90 \mathrm{hrs}$ at room temperature.

\subsubsection{Effect of Different Concentrations of Phosphate}

The effect of phosphate concentration in the enzyme production was investigated by adding $0.1 \%, 0.3 \%, 0.5 \%$, $0.7 \%, 0.9 \%$ and $1.4 \%$ of phosphate in the medium at $\mathrm{pH} 5.6$ for $90 \mathrm{hrs}$ of incubation.

*Statistical analysis: All the experiments were repeated thrice and standard deviation was calibrated.

\section{RESULTS}

\subsection{Soil Sample Analysis}

Fungal isolate from soil have beneficial role in industrial area $[20,21]$ and their saprophytic ability mainly depends on the chemistry, texture, salinity, and water holding capacity [22, 23]. Some of the physico chemical characteristics of the soil from which the microorganisms isolated are shown in table 1.1. Soil $\mathrm{pH}$ is one of the most indicative measurements of the soil because it is an important factor for the survival of microorganisms [24]. In the present study the $\mathrm{pH}$ of the soil was determined to be 7.0 .

Table 1.1: Physico chemical characteristics of the soil samples

\begin{tabular}{|l|c|}
\hline Characteristics & Soil sample \\
\hline Color & Brown \\
\hline Odour & Normal \\
\hline $\mathrm{pH}$ & 7.0 \\
\hline Organic carbon $(\mathrm{kg} / * \mathrm{~A})$ & 65 \\
\hline Phosphorous $(\mathrm{kg} / * \mathrm{~A})$ & 0.60 \\
\hline Potassium $(\mathrm{kg} / * \mathrm{~A})$ & 0.56 \\
\hline
\end{tabular}

$$
* A=\text { Acre }
$$

\subsection{Isolation and Identification of Fungal Isolates}

\subsubsection{Morphological Characterization of Isolates}

There are various methods for isolating the fungi $[25,26]$ but the simplest one is dilution plate method and the lifting of conidia from sporulating conidiophores. According to the starch hydrolyzing capacity, five fungal isolates were isolated from soil samples. Among these only one isolate $(15 \mathrm{~F})$ showed the maximum zone of clearance on starch agar media as shown in figure 1.1 (a). The isolate $(15 \mathrm{~F})$ was characterized morphologically by lactophenol cotton blue staining and scanning electron microscopic analysis the details are presented in table 1.2. The macro and microscopic images of isolate $(15 \mathrm{~F})$ was shown in figure 1.2.

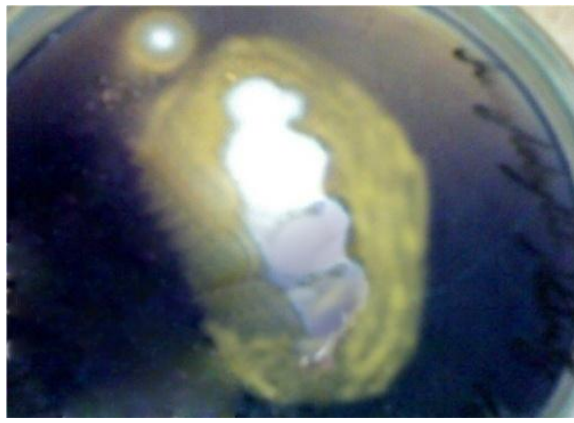

Fig 1.1 (a) Starch hydrolyzing activity of isolate (15F) on starch agar media

Table 1.2: Macroscopic and microscopic characteristics of fungal isolate $(15 \mathrm{~F})$.

\begin{tabular}{|l|l|}
\hline Parameter & Isolate \\
\hline Colony color & $\begin{array}{l}\text { Green } \\
\text { powdery. }\end{array}$ \\
\hline $\begin{array}{l}\text { Colony diameter } \\
(\mathrm{cm})\end{array}$ & $3.0-6.0$ \\
\hline Hyphae & $\begin{array}{l}\text { Septate } \\
\text { branched. }\end{array}$ \\
\hline Spore arrangement & $\begin{array}{l}\text { Bunch of } \\
\text { spores with } \\
\text { single chains. }\end{array}$ \\
\hline Spore shape & Oval \\
\hline
\end{tabular}

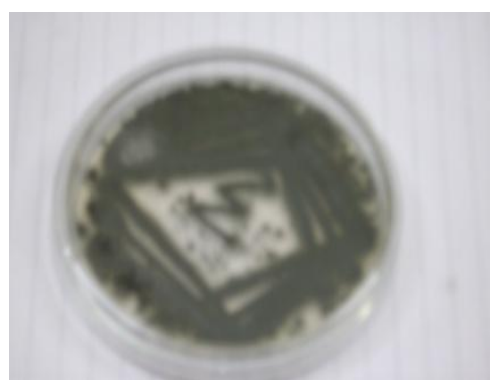

(a) Isolate-15F macroscopic image 


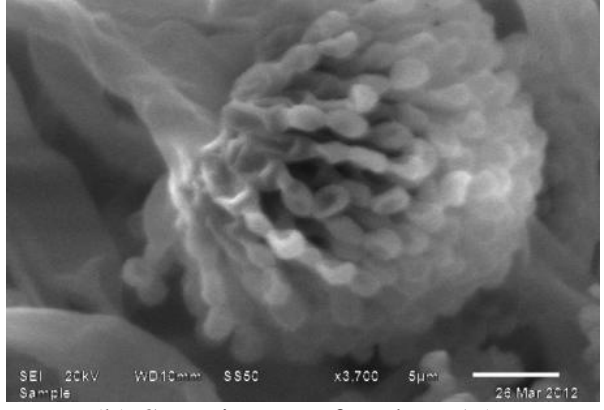

(b) SEM image of Isolate- $15 \mathrm{~F}$

Fig 1.2: Macro and Microscopic images of fungal isolate $(15 \mathrm{~F})$.

\subsubsection{Molecular Characterization of Isolate (15F)}

Molecular characterization of the isolate $(15 \mathrm{~F})$ was performed by ITS/5.8S rRNA and $\beta$-tubulin gene sequence analysis and the isolate was confirmed as Aspergillus fumigatus (MTCC Acc No 11399). ITS/5.8S rRNA gene sequence, $\beta$-tubulin gene sequence data and phylogenetic Evolutionary relationship of taxa based on ITS Sequence, $\beta$-tubulin gene Sequence data of Aspergillus fumigatus were shown in figures 2(a), 2(b), 2(c), 2(d).

\section{ATGCTTAAGTTCAGCGGGTATCCCTACTGATCCGAGG} TCAACCTTAGAAAAATAAAGTTGGGTGTCGGCTGGC GCCGGCCGGGCCTACAGAGCAGGTGACAAAGCCCCA TACGCTCGAGGACCGGACGCGGTGCCGCCGCTGCCT TTCGGGCCCGTCCCCCGGGAGAGGGGGACGGGGGCC CAACACACAAGCCGTGCTTGAGGGCAGCAATGACGC TCGGACAGGCATGCCCCCCGGAATACCAGGGGGCGC AATGTGCGTTCAAAGACTCGATGATTCACTGAATTCT GCAATTCACATTACTTATCGCATTTCGCTGCGTTCTTC ATCGATGCCGGAACCAAGAGATCCGTTGTTGAAAGT TTTAACTGATTACGATAATCAACTCAGACTGCATACT TTTCAGAACAGCGTTCATGTTGGGGTCTTCGGCGGGC GCGGGCCCGGGGGCGCAAGGCCTCCCGGCGGCCGTC GAAACGGCGGGCCCGCCGAAGCAACAAGGTACGAT AGACACGGGTGGGAGGTTGGACCCAGAGGGCCCTCA CTCGGTAATGATCCTTCCGCAGGTTCACCTACGGAAA CCTTGTTACGAT

Fig 2(a) Aspergillus fumigatus, Strain “(15F)”, ITS/5.8S rRNA gene sequence data

GTGCTGCTTTCTGGTATGTCTTGACCTCAAAGCTTGG ATGACGGGTGATTGGGATCTCTCATCTTAGCGGGNTA CCTCCATGGGTTCAGCCTCACTGTCATGGGTATCAGC TAACAAATCTACAGGCAGACCATCTCTGGTGAGCAT GGCCTTGACGGCTCTGGCCAGTAAGTTCGACCTATAT CCTCCCAATTGAGAAAGCGGCGGAAACACGGAAAAC AAGGAAGAAGCGGACGCGTGTCTGATGGGAAATAAT AGCTACAATGGCTCCTCCGATCTCCAGCTGGAGCGTA TGAACGTCTATTTCAACGAGGTGTGTGGATGAAACTC TTGATTTATACTATTTCGGCCAACATCTCACGATCTG
ACTCGCTACTAGGCCAACGGTGACAAATATGTTCCTC GTGCCGTTCTGGTCGATCTCGAGCCTGGTACCATGGA CGCTGTCCGTGCCGGTCCCTTCGGCGACTATTCCGTC CCGACAACTTCGTCTTCGGCCAGTCCGGTGCTGGTAA CAACTGGGCCAAGGGT

Fig 2(b) Aspergillus fumigatus, Strain “(15F)”, $\beta$-tubulin gene sequence data

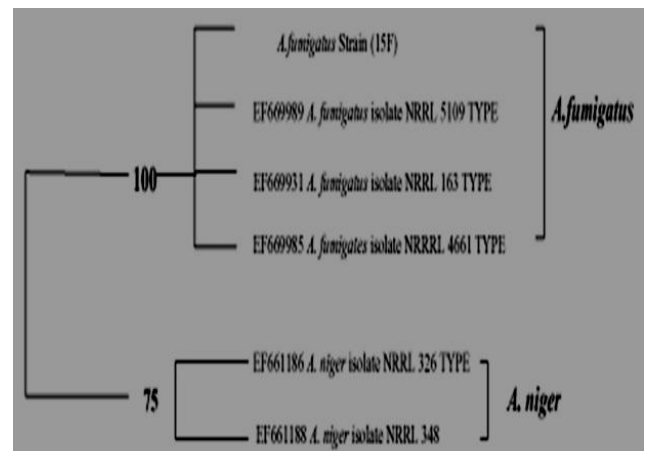

Fig 2(c) Evolutionary relationship of taxa based on ITS Sequence data.

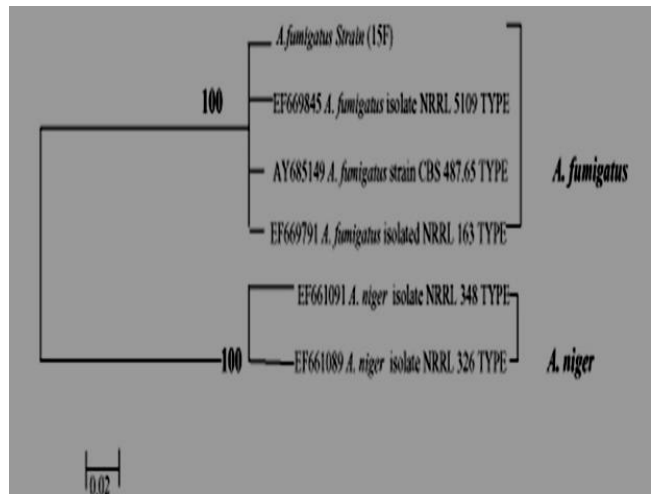

Fig 2(d) Evolutionary relationship of taxa based on $\beta$-tubulin gene Sequence data.

\subsection{Effect of Different Cereal Flours on Enzyme}

\section{Production}

Addition of different cereal flours like finger millet, pearl millet, sorghum, sammai and horse gram to the fermentation medium, maximum enzyme activity was observed with finger millet $(157 \pm 0.5 \mathrm{U} / \mathrm{mg}$ protein) and minimum with sammai ( $84 \pm 0.5 \mathrm{U} / \mathrm{mg}$ protein) by Aspergillus fumigatus at $30^{\circ} \mathrm{C}$ temperature as shown in figure3(a). 


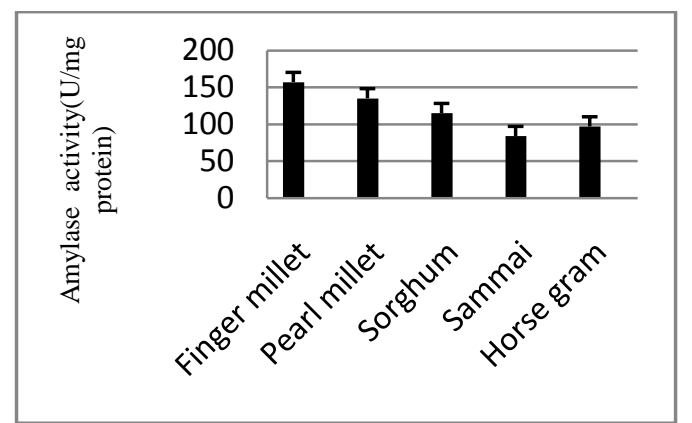

*Different cereal flours on amylase production by Aspergillus fumigatus at $30^{\circ} \mathrm{C}$ for $48 \mathrm{hrs}$ of incubation

Fig 3(a) Effect of different cereal flours on amylase production

\subsection{Effect of Incubation Period}

Incubation period varies with the type of enzyme production. Short incubation period offers potential for inexpensive production of enzyme [27]. As shown in figure 3(b), incubation of fermentation medium at different time intervals $18,36,54,72$, and $90 \mathrm{hrs}$, maximum $(210 \pm 0.6 \mathrm{U} / \mathrm{mg}$ protein $)$ and minimum $(50 \pm 0.63 \mathrm{U} / \mathrm{mg}$ protein) enzyme activity was observed within $72 \mathrm{hrs}$ and $18 \mathrm{hrs}$ respectively at $30^{\circ} \mathrm{C}$ temperature.

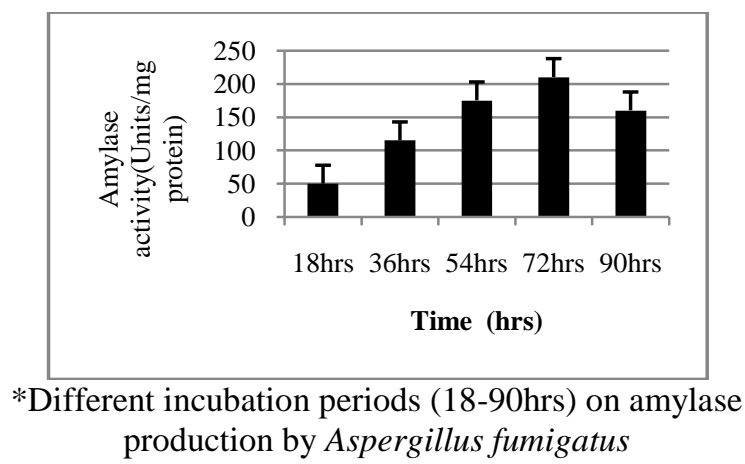

Fig 3(b) Effect of incubation period on amylase production

\subsection{Effect of Temperature}

Incubation of fermentation medium at different temperatures $\left(25^{\circ} \mathrm{C}, 30^{\circ} \mathrm{C}, 35^{\circ} \mathrm{C}, 40^{\circ} \mathrm{C}\right.$, and $\left.45^{\circ} \mathrm{C}\right)$ was carried out. Maximum $(230 \pm 0.7 \mathrm{U} / \mathrm{mg}$ protein) and minimum $(48 \pm 0.57 \mathrm{U} / \mathrm{mg}$ protein) amylase activity was observed at temperature $35^{\circ} \mathrm{C}$ and $25^{\circ} \mathrm{C}$ respectively by Aspergillus fumigatus at $72 \mathrm{hrs}$ of incubation period as shown in figure 3(c).

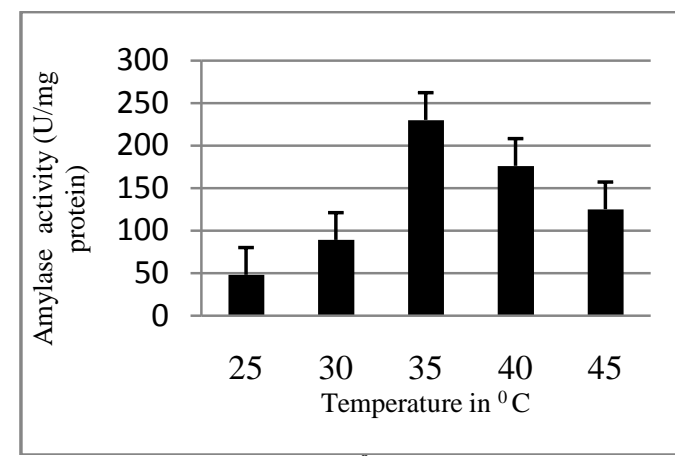

*Different temperatures $\left(25-45^{0} \mathrm{C}\right)$ on amylase production by Aspergillus fumigatus with finger millet at $72 \mathrm{hrs}$ of incubation

Fig 3(c) Effect of different temperatures on amylase production

\subsection{Effect of Different Nitrogen Sources on Enzyme Production}

Ammonium nitrate, ammonium chloride, ammonium sulphate, and sodium nitrate were used as nitrogen sources separately along with fermentation media. Maximum $(128 \pm 0.43 \mathrm{U} / \mathrm{mg}$ protein) and minimum (54 $\pm 0.5 \mathrm{U} / \mathrm{mg}$ protein) amylase activity was observed in Ammonium nitrate and ammonium chloride respectively with Aspergillus fumigatus at $35^{\circ} \mathrm{C}$ for $72 \mathrm{hrs}$ of incubation as shown in figure 3 (d).

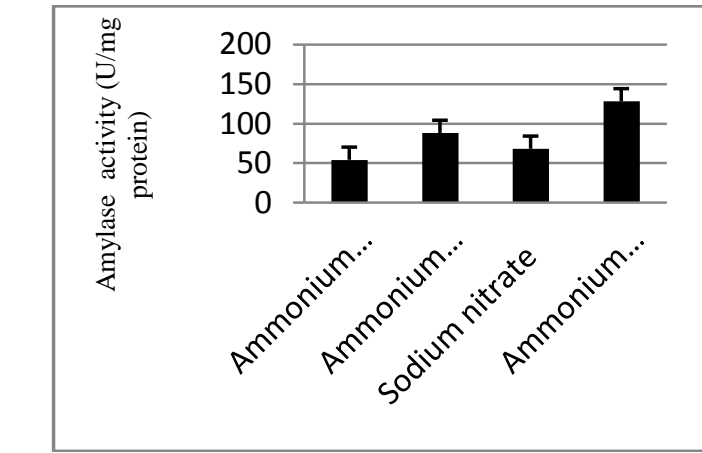

*Different nitrogen sources on amylase production by Aspergillus fumigatus at $35^{\circ} \mathrm{C}$ for 72

Fig 3(d) Effect of different nitrogen sources on amylase production

\subsection{Effect of Different Concentrations of Phosphate}

Incubation of fermentation medium with different concentrations of Phosphate $(0.1 \%, 0.3 \%, 0.5 \%, 0.7 \%, 0.9 \%$, and $1.4 \%)$ the maximum $(210 \pm 0.65 \mathrm{U} / \mathrm{mg}$ protein) and minimum $(35 \pm 0.7 \mathrm{U} / \mathrm{mg}$ protein) amylase activity was observed in $0.9 \%$ and $0.1 \%$ phosphate respectively with Aspergillus fumigatus at $35^{\circ} \mathrm{C}$ for $72 \mathrm{hrs}$ of incubation as shown in figure $3(\mathrm{e})$. 


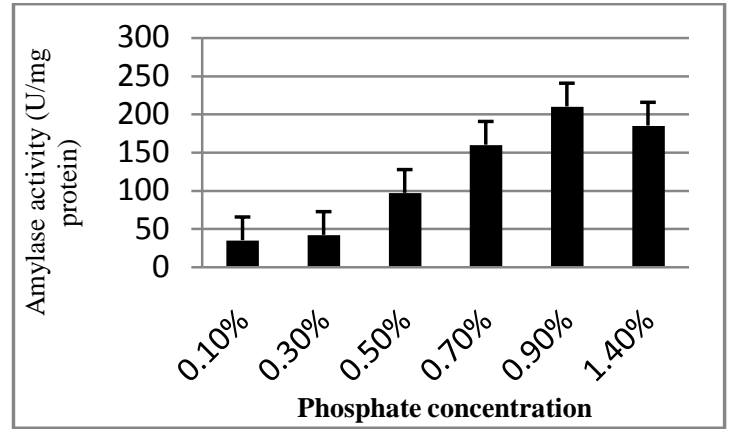

*Different percentages of phosphate concentrations on amylase production by Aspergillus fumigatus at $72 \mathrm{hrs}$ of incubation.

Fig3 (e) Effect of different phosphate concentrations on amylase production

\section{DISCUSSION}

Isolation of fungi from soil samples and the rapid screening by plating on starch agar plates led to finding of five fungal isolates capable of producing amylase. Morphological and molecular characterization confirmed the isolate $(15 \mathrm{~F})$ as Aspergillus fumigatus. Different cereal flours used in submerged fermentation, maximum amylase activity $(157 \pm 0.5 \mathrm{U} / \mathrm{mg}$ protein) was observed in Aspergillus fumigatus with finger millet at $30^{\circ} \mathrm{C}$ for $48 \mathrm{hrs}$ of incubation. Gomes [28] reported that amylase production was maximum (140U/mg protein) with sorghum flour with Aspergillus niger at $72 \mathrm{hrs}$ of incubation period. Incubation of fermentation medium at different time intervals the maximum amylase activity $(210 \pm 0.6 \mathrm{U} / \mathrm{mg}$ protein) was observed at $72 \mathrm{hrs}$ in Aspergillus .fumigatus. Dhurba Sharma and Shukla [29] reported the maximum production of amylase $(185 \mathrm{U} / \mathrm{ml})$ with Aspergillus fumigatus for 6 days of incubation at $30^{\circ} \mathrm{C}$. Incubation at different temperatures the maximum amylase activity $\left(230 \pm 0.7 \mathrm{U} / \mathrm{mg}\right.$ protein) was observed at $35^{\circ} \mathrm{C}$ by Aspergillus fumigatus. Got [30] reported maximum production of amylase $(193 \mathrm{U} / \mathrm{ml})$ and glucoamylase $(200 \mathrm{U} / \mathrm{ml})$ by Aspergillus fumigatus at $37^{0} \mathrm{C}$. By the effect of different nitrogen sources maximum activity of amylase $(128 \pm 0.43 \mathrm{U} / \mathrm{mg}$ protein) was observed in Aspergillus fumigatus with ammonium nitrate. It was reported that peptone, sodium nitrate and casein hydrolysate were good nitrogen supplements for amylase production in Aspergillus fumigatus by Got [30], in Aspergillus niger by Pandey [31] and in Aspergillus oryzae by Pederson and Nielson [32]. With different phosphate concentrations, maximum amylase activity $(210 \pm 0.65 \mathrm{U} / \mathrm{mg}$ protein) was observed in $0.9 \%$ of phosphate concentration by Aspergillus fumigatus at $35^{\circ} \mathrm{C}$ for $72 \mathrm{hrs}$ of incubation period. Nguyen [33] reported that Thermomyces lanuginosus showed the maximum amylase activity $(190 \mathrm{U} / \mathrm{ml})$ with $0.7 \%$ of phosphate concentration at $30^{\circ} \mathrm{C}$ of incubation. Peixoto [34] elicited same rate of amylase activity with Rhizophus microsporus, a thermotolarent fungi when compared with Aspergillus fumigatus at $0.5 \%$ of phosphate concentration.

\section{CONCLUSIONS}

The fungal isolates were collected from soil, analysis of soil was performed. Morphological characterization of isolate (15F) was carried out through scanning electron microscope which reports that the conidiophores are in septate, oval shape. The molecular characterization of the isolate $(15 \mathrm{~F})$ was carried out with the help of ITS/5.8 S rRNA and $\beta$-tubulin gene sequence analysis and the isolate was confirmed to be Aspergillus fumigatus (MTCC Acc No 11399), which is closely related to Aspergillus niger. Optimization of cultural conditions was done for maximal production of amylase using different cereal flours, incubation periods, temperatures, nitrogen sources and with different phosphate concentrations. The maximum amylase activity $(230 \pm 0.7 \mathrm{U} / \mathrm{mg}$ protein) was observed on production media containing finger millet as the carbon source, and ammonium nitrate as the nitrogen source at $35^{\circ} \mathrm{C}$ for $72 \mathrm{hrs}$ incubation period by Aspergillus fumigatus. The carbon source was cheaply available throughout the year and easy for storage of seeds for further usage. Amylases have wide range of applications in lactic acid production, antibiotics, food, bio fuel, and detergent industries. Amylolytic activity of filamentous fungi helps in the production of lactic acid. Lactic acid mainly helps in the formation of biodegradable plastics. Applications of amylase in food industries extensively employed in baking, brewing, preparation of digestive aids, production of cakes, fruit juices and starch syrups. Ethanol is the most utilized liquid bio fuel. The bioconversion of starch into ethanol involves liquefaction and saccharification. Amylases are used in textile industry for desizing process.

\section{ACKNOWLEDGEMENTS}

The authors thank the DST-PURSE program for financial support to carry out this work.

\section{REFERENCES}

[1]. Prakasham RS, Rao CS, Rao RS, and Sarma PN. (2006). Enhancement of acid amylase production by an isolated A.awarmori. J. Applied Microbiol., 102: 204-211.

[2]. Abu EA, Ado SA, James DB. (2005). Raw starch degrading amylase production by mixed culture of Aspergillus niger and Saccharomyces cervisae grown on Sorghum pombae. Afr.J.Biotechnol., 4: 785-790.

[3]. Sidkey NM, Abo Shadi HA, Al-Mutrafy AM, Sefergy F, Al-Reheily N. (2010). Screening of microorganisms is isolated from some enviro-Agro-Industrial wastes in Saudi Arabia for Amylase production. J. Americ.Sci., 6(10): 926939.

[4]. Gupta R, Gigras P, Mahapara H, Goswani VK. and Chuhan B. (2003). Microbial $\alpha$-amylases: A Biotechnological prospective process Biochem., 38: 1599-1616.

[5]. Duochuan L, Yijun Y, Youliang P, Chongyao S, Peijin Z and Yicum H. (1997). Purification and properties of a thermostable alpha amylase from thermophilic fungus, Thermomyces lanuginosus. Acta-Microbiol SIN., 37: 107-114. [6]. Suganthi R, Benazir JF, Santhi R, Ramesh Kumar V, Anjana Hari, Nidhiya KA, Kavitha G, and Lakshmi R. (2011). Amylase production by Aspergillus niger under solid state fermentation using agro industrial wastes. International 
Journal of Engineering science and Technology. 3(2): 17561763.

[7]. Abe J, Bergman FW, Obeta K, Hizukuri S. (1988). Production of the raw starch digesting amylase of Aspergllus sp. k.27. Appl.Microbiol Biotechnol., 27:447-450.

[8]. Pandey A, Nigam P, Soccol VT, Singh D, Mohan R. (2000). Advances in Microbial amylases, Biotechnol., Appl.Biochem., 31: 135-152.

[9]. Alexander M. (1961). In: Introduction to Soil microbiology, Wiley Eastern Ltd., New Delhi.

[10]. Walkely AJ. and Black IA. (1934). Estimation of soil organic carbon by Chromic acid titration method. J.Soil sci., 37: 29-38.

[11]. Jackson MA. (1997). Optimizing nutritional conditions for the liquid culture production of effective fungal biological control agents. J. Microbiol Biotechnol., 19: 180187.

[12]. Chapman HD, and Pratti PJ, (1961). In : Method of analysis for soils, plants and water. University of California, Division of agricultural sciences.

[13]. Warcup JH. (1950). The soil-plate method for isolation of fungi from the soil. Nature, 166: 117-118.

[14]. Domsch KW, Games, Anderson TH. (1980). Compendium of soil fungi. Academic press, London, ISBN10:0122204018: 22-23.

[15]. Barnett HL and Hunter BB. (1972). Illustrated genera of fungi Imperfect. $3{ }^{\text {rd }} \mathrm{Edn}$, Burgess published company, Minneapolis,MN, USA, 331-339.

[16]. Saitou N. and Nei M. (1987). The neighbor-joining method: A new method for reconstructing phylogenetic trees. Molecular Biology and Evolution 4:406-425.

[17]. Felsenstein J. (1985). Confidence limits on phylogeneis: An approach using the bootstrap. Evolution 39: 783-791.

[18]. Kimura M. (1980). A simple method for estimating evolutionary rate of base substitutions through comparative studies of nucleotide sequences. Journal of Molecular Evolution 16:111-120.

[19]. Tamura K, Peterson D, Peterson N, Stecher G, Nei M and Kumar S. (2011). MEGA5: Molecular evolutionary Genetics Analysis using Maximum Likelihood, Evolutionary Distance, and Maximum Parsimony Methods. Molecular Biology and Evolution 2731-2739.

[20]. Bergquist P, Teo V, Gibbs M, Curach N, and Nevalainen K. (2003). Recombinant bleaching enzymes from Thermophiles expressed in fungal hosts. In: Mansfield, S.D. Saddler, J.n (Eds). Applications of enzymes to lignocellulosics. Amer.Chem.Soc.Symposium series: 855, 435445.

[21]. Nevalainen H, and Teo VSJ. (2005). Enzyme production in industrial fungi. Role of Molecular Genetics. In: Arora D.K.(Ed.), Applied Mycology and Biotechnology., 3, Fungal Genomics, Elesevier science 468-474.

[22]. Wanwright M. and Falih AMK. (1995). In: An introduction to fungal Biotechnology. Wiley Chichester.

[23]. Ortuno A, Noguere J, Hernansaez A, ArmeroT. (1977). Phosphoric metabolism of Aspergillus niger in calcareous and saline. Microbiol., 30: 101-112.

[24]. Durghi HM, and Bottomley PJ. (1983). Effect of acidity on the composition of an indigenous of Trifolium sbterraneum. L., App. Environmen. Microbiol., 46: 12071213.
[25]. Kelman A. (1967). In: Source book of laboratory exercises in plant pathology. Source book committee of American Phytopathological Society. W. H Freeman and Co., San Francisco, 180.

[26]. Stevens RB. (1974). In: Mycology Guidebook. University of Washington Press, Seattle, 532.

[27]. Sonjoy S, Bill Bex, Houston KH. (1995). Cellular activity of Trochoderma ressei (RUT-C30) on municipal solid waste. Appl. Biochem. Biotechnol., 15: 145-153.

[28]. Gomes E, Souza SR, Grandi RP and Silva ED. (2005). Production of thermostable glucoamylase by newly isolated A.flavus. 1.1 and Thermomyces lanuginosus A 13.37. Braz. J. Microbiol., 36: 75-82.

[29]. Dhurba Sharma and Shukla Ak. (2008).Starch hydrolysis and Amylase activity of Aspergillus and Chaetomium. Asian Journal of Biochemistry. 3: 284-289.

[30]. Got CE, Barbosa EP, Kistnera CL, Moreira FG, Lenartovicz V, and Peralta RM. (1998). Production of amylase by A.fumigatus using methyl-D-glucoside, asynthetic analog of maltose, as substrate. FEMS Microbiol., 167: 139-143.

[31]. Pandey A, Selvakumar P, and Ashakumary L. (1994). Glucose production by A.niger on rice bran is improved by addition of nitrogen sources . World $J$ .Microbiol.Biotechnol.,10: 348-349.

[32]. Pederson H, and Nielson J. (2000). The influence of nitrogen sources on amylase productivity of A.oryzae in continuous cultures. Appl.Microbiol.Biotechnol., 53: 278-281. [33]. Nguyen QD, Rezessy-Szabo JM and Hoschke A. (2000). Optimisation of composition of media for the production of amylolytic enzymes by Thermomyces lanuginosus ATCC 34626. Food Technol. Biotechnol., 38: 229-234.

[34]. Peixoto SC, Jorge JA, Terenzi HF, and Polizeli TM. (2003). Rhizopus microsporus var. rhizopodiformis: A thermotolarent fungus with potential for production of thermostable amylases. Int. Microbiol., 6: 269-273.

\section{BIOGRAPHIES}

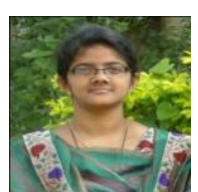

P.V. Ratna sri, Research scholar Department of Microbiology College of science and technology Andhra University

Visakhapatnam,-530 003 Andhra Pradesh, India, Email id: ratnasrii@gmail.com

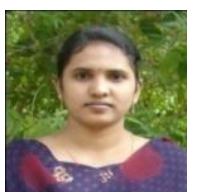

B.K.M. Lakshmi, Research scholar Department of Microbiology College of science and technology Andhra University

Visakhapatnam- 530003 Andhra Pradesh, India, Email id: Kamalab42@gmail.com

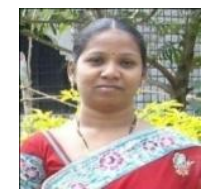

K. Ambika Devi, Research scholar Department of Microbiology College of science and technology Andhra University

Visakhapatnam,-530 003 Andhra Pradesh, India, Email id: Ambicadevi24@gmail.com

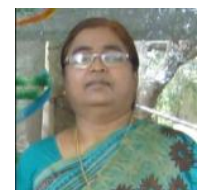

Dr. K.P.J Hemalatha Professor and Head Department of Microbiology Andhra University Visakhapatnam-530 003 Andhra Pradesh India, Email id: hemalathakpj@gmail.com 